\title{
Analisa Teknis dan Ekonomis Pengembangan Industri Pendukung Konsol Kapal (Ship Console) di Indonesia
}

\author{
Anisa Prasetyo dan Triwilaswandio Wuruk Pribadi \\ Jurusan Teknik Perkapalan, Fakultas Teknologi Kelautan, Institut Teknologi Sepuluh Nopember (ITS) \\ Jl. Arief Rahman Hakim, Surabaya 60111 Indonesia \\ e-mail: triwilas.its@gmail.com
}

\begin{abstract}
Abstrak - Industri konsol kapal di Indonesia masih perlu dikembangkan untuk mendukung peningkatan jumlah komponen lokal dalam industri perkapalan. Melihat besarnya peluang dan pasar industri konsol kapal di Indonesia, maka dilakukan penelitian tugas akhir analisa teknis dan ekonomis pengembangan industri pendukung konsol kapal (ship console) di Indonesia. Konsol kapal yang dimaksud adalah bridge control console, engine control console, cargo control console, water ballast control console, bridge wing control console. Tujuan dari tugas akhir ini adalah melakukan analisa teknis meliputi pemilihan lokasi, proses produksi, pemeriksaan hasil produksi, penentuan kapasitas produksi, peralatan dan mesin yang digunakan dalam proses pembuatannya, serta pembuatan layout dari pabrik dengan luas bangunan $2728 \mathrm{~m}^{2}$ dan luas tanah $3886 \mathrm{~m}^{2}$ berada pada Desa Karangploso, Kec. Benjeng, Kab. Gresik, Jawa Timur. Analisa ekonomis meliputi analisa kondisi pasar di Indonesia untuk permintaan konsol kapal dalam lima tahun yang akan datang. Biaya investasi pembangunan industri ini kira-kira sebesar $\mathbf{R p}$ 14.186.000.000,00 yang berupa biaya pembelian tanah, pembangunan, pembelian peralatan dan mesin. Selanjutnya dilakukan perhitungan biaya operasional dan pemasukan perusahaan agar dapat melakukan analisa kelayakan investasi dengan menggunakan metode Break Event Point, Net Present Value, dan Internal Rate of Return yang hasilnya digunakan untuk menentukan kelayakan pengembangan dari industri konsol kapal di Indonesia. Berdasarkan analisa yang telah dilakukan Break Event Point terjadi pada 6 tahun 8 bulan dengan keuntungan kirakira sebesar Rp 1.507.000.000,00. Nilai Net Present Value kira-kira sebesar Rp 4.408.000.000,00. Nilai Internal Rate of Return sebesar $11.38 \%$ lebih besar dari bunga bank yang telah ditetapkan yaitu $10.25 \%$. Hal tersebut dikarenakan besarnya potensi pasar di Indonesia dan sedikitnya jumlah kompetitor pada industri konsol kapal.
\end{abstract}

Kata Kunci — industri pendukung kapal, kelayakan investasi, konsol kapal

\section{PENDAHULUAN}

$I^{1}$ NDUSTRI perkapalan merupakan industri yang potential di Indonesia, seiring dengan visi pemerintah yang ingin menjadikan "Indonesia sebagai Poros Maritim Dunia". Salah satu kebijakannya adalah melarang Institusi-Institusi di bawah Pemerintah untuk membeli kapal baru maupun bekas dari galangan luar negeri, melainkan mewajibkan institusi-institusi tersebut membeli kapal baru dari galangan dalam negeri. Selain itu salah satu program pemerintah untuk mewujudkan Visi
Maritim Indonesia adalah dengan program "Tol Laut". Yang bertujuan untuk konektivitas wilayah-wilayah Indonesia dengan menggunakan kapal. Pemerintah sudah mulai menyiapkan lima pelabuhan besar di wilayah Indonesia dan pelabuhan-pelabuhan kecil lainnya untuk menyongsong kebijakan tersebut. Di samping itu, program "Tol Laut" membutuhkan kapal-kapal perintis untuk konektivitas antar pulau di Indonesia. Hal ini mengakibatkan semakin meningkatnya permintaan pembangunan kapal baru di galangan kapal Nasional.

Industri galangan kapal di Indonesia mempunyai permasalahan, yaitu tingginya bea masuk impor dan suku bunga kredit bagi industri perkapalan Nasional. Tingginya bea masuk impor sangat berpengaruh terhadap industri perkapalan di Indonesia karena sebagian besar bahan baku pembuatan kapal masih diimpor. Sekitar tujuh puluh persen pasokan peralatan dan komponen berasal dari luar negeri. Ketergantungan terhadap impor membuat industri perkapalan kurang berkembang. Padahal bila dibandingkan dengan industri perkapalan di luar negeri mampu menyokong sembilan puluh persen bahan baku dari produk lokal mereka [1]. Sebenarnya permasalahan tersebut mulai ditindaklanjuti pemerintah dengan mengeluarkan paket kebijakan jilid II yang berisi "Pemerintah Tak Pungut PPN untuk Alat Transportasi”. Kebijakan tersebut telah terbit lewat Peraturan Pemerintah Nomor 69 tahun 2015 tentang impor dan penyerahan alat angkutan tertentu dan penyerahan jasa kena pajak, terkait angkutan tertentu tidak dipungut PPN. Pemerintah akan memberikan insentif berupa tidak memungut PPN untuk beberapa alat transportasi, terutama adalah galangan kapal, kereta api, pesawat, dan termasuk suku cadangnya [2]. Salah satu Industri penunjang dan pendukung adalah industri konsol kapal. Industri konsol kapal belum mendapatkan perhatian khusus dikarenakan belum adanya industri yang menghasilkan produk tersebut yang berkualifikasi Internasional. Dengan adanya industri konsol kapal di Indonesia, diharapkan bisa mendukung industri galangan kapal Nasional untuk mengurangi biaya pembangunan kapal, sehingga dapat meningkatkan daya saing terhadap industri galangan kapal luar Negeri. 


\section{TINJAUAN PUSTAKA}

\section{A. Konsol Kapal}

Konsol Kapal adalah panel dari sebuah sistem terintegrasi yang terdapat pada kapal untuk mengontrol sistem navigasi, sistem komunikasi, sistem kemudi, sistem propulsi, sistem alarm, sistem kendali mesin, sistem kendali muatan, dan sistem kendali water ballast. Berikut adalah beberapa macam konsol kapal:

\section{1) Bridge Control Console (BCC)}

Bridge control console adalah panel kemudi yang dipasang pada anjungan kapal untuk mengontrol sistem navigasi, sistem komunikasi, sistem kemudi, sistem propulsi, dan sistem alarm.

2) Engine Control Console (ECC)

Engine control console adalah panel yang terdapat pada ruang kendali mesin merupakan bagian terpenting dalam sistem kontrol otomatis di dalam kapal.

3) Cargo Control Console (CCC)

Cargo control console adalah panel yang terdapat pada cargo control room yang digunakan untuk mengontrol muatan saat bongkar/muat, mengetahui stabilitas kapal, dan draft kapal.

4) Engine control Water Ballast Control Console (WBCC) Water ballast control console adalah panel yang terdapat pada water ballast control room yang digunakan untuk mengontrol volume air sebagai ballast untuk menyeimbangkan kapal pada kondisi muatan kosong maupun sebagian.

5) Bridge Wing Control Console (BWCC)

Water ballast control console adalah panel yang terdapat pada anjungan kapal yang digunakan untuk mengontrol olah gerak kapal ketika akan masuk ke pelabuhan.

6) Helicopter Control Console (HCC)

Helicopter control console adalah panel yang terdapat pada ruang boat deck yang digunakan untuk proses landing dan take off helicopter pada geladak kapal. Penempatan dari helicopter control console adalah di dalam ruang anjungan kapal.

\section{B. Metode Penilaian Investasi}

Kriteria investasi terbagi menjadi kriteria internal dan eksternal dimana yang internal menggunakan metode Pay Back Period, Internal Rate of Return, dan Net Present Value. Sedangkan yang eksternal adalah metode Benefit Cost Ratio. Berikut ini adalah metode-metode yang digunakan untuk kelayakan investasi:

1) Metode Pay Back Period (PBP) [3]

Keuntungan dari metode ini adalah:

a. Mudah dimengerti

b. Lebih mengutamakan investasi yang menghasilkan aliran kas yang lebih cepat

c. Beranggapan bahwa semakin lama waktu pengembalian, semakin tinggi risikonya

d. Cukup akurat untuk mengukur nilai investasi yang dibandingkan untuk beberapa kasus dan bagi pembuat keputusan
Kelemahan dari metode ini adalah:

a. Mengabaikan nilai waktu dari pada uang (time value of money)

b. Mengabaikan penerimaan-penerimaan investasi atau proses setelah Pay Back Periode tercapai

2) Metode Net Present Value (NPV) [4]

Keuntungan dari metode ini adalah:

a. Memperhatikan nilai waktu dari pada uang (time value of money)

b. Mengutamakan aliran kas yang lebih awal

c. Tidak mengabaikan aliran kas selama periode proyek atau investasi

Kelemahan dari metode ini adalah

a. Lebih sulit penerapannya dari pada Pay Back Periode

b. Memerlukan perhitungan Cost of Capital sebagai Discount Rate

3) Metode Internal Rate of Return (IRR) [5]

Kelebihan dari metode ini adalah:

a. Tidak mengakibatkan aliran kas selama periode proyek

b. Memperhitungkan nilai waktu daripada uang

c. Mengutamakan aliran kas awal daripada aliran kas belakangan

Kelemahan dari Metode ini adalah:

a. Memerlukan perhitungan COC (Cost of Capital) sebagai batas minimal dari nilai yang mungkin dicapai

b. Lebih sulit dalam melakukan perhitungan

\section{Forecasting}

Pada umumnya terdapat dua metode dalam pengukuran kuantitatif, yaitu: metode serial waktu (deret berkala, time series) dan metode kausal. Metode serial waktu adalah metode yang digunakan untuk menganalisa serangkaian data yang merupakan fungsi waktu, sedangkan metode kausal mengasumsikan bahwa faktor yang diperkirakan menunjukkan adanya hubungan sebab-akibat dengan satu atau beberapa variabel bebas (indenpendency), misalnya permintaan akan reparasi kapal berhubungan dengan jumlah kapal yang beroperasi.

Dalam menentukan metode peramalan tertentu, tidak bisa dengan langsung memakai salah satu dari sekian banyak metode yang ada. Melainkan harus melalui pertimbanganpertimbangan yang sesuai untuk dapat menghasilkan prakiraan yang mendekati kebenaran. Berikut adalah klasifikasi metode yang dapat diterapkan [6], yaitu:

1) Metode Kualitatif

Metode ini digunakan bila hanya terdapat sedikit data historis. Pada umumnya digunakan dalam meramal perkenalan produk dan jasa baru. Caranya adalah dengan menganalisa situasi di pasar atau dengan pendekatan sistematik.

2) Metode Kuantitatif

Metode ini dilakukan dengan cara membuat analisa yang selanjutnya akan diproyeksikan kedalam peramalan permintaan atau demand untuk waktu yang akan datang.

3) Metode Kuantitatif Kausal

Metode ini dapat digunakan bila terdapat data historis dan 
data yang berkaitan dengan faktor ekonomi dengan pola kecenderungan musiman dan fluktuasi.

\section{Kriteria Penentuan Lokasi Industri}

Dalam kriteria penentuan lokasi industri dilakukan beberapa pertimbangan [7], yaitu: kondisi lahan, ketersediaan tenaga kerja, ketersediaan bahan baku, pemasaran, rencana tata ruang terkait penentuan lokasi, modal, dan kecukupan infrastruktur. Berikut adalah penjelasannya:

1) Kondisi Lahan

Kondisi-kondisi lahan dalam penentuan lokasi industri konsol kapal terdiri atas kemampuan lahan dan penggunaan lahan.

2) Ketersediaan Tenaga Kerja

Penentuan suatu lokasi industri mempertimbangkan ketersediaan tenaga kerja, seberapa banyak jumlah angkatan kerja yang secara resmi terdaftar sebagai pengangguran atau sedang mencari pekerjaan.

3) Ketersediaan Bahan Baku

Bahan baku merupakan faktor pertimbangan yang sangat penting dalam menentukan lokasi industri konsol kapal yang terdiri atas kuantitas bahan baku, kuantitas bahan baku, dan jarak bahan baku.

4) Pemasaran

Permintaan pasar dalam hal ini merupakan besaran pasar bagi industri konsol kapal. Adapun besaran permintaan pasar sesuai dengan jarak dari klien lokasi.

5) Rencana Tata Ruang Terkait Penetuan Lokasi

Faktor yang tidak kalah penting guna mewujudkan pembangunan industri konsol kapal adalah menyesuaikan dengan rencana tata ruang yang ada [8].

6) Modal

Salah satu faktor terpenting dalam membangun sebuah usaha adalah modal awal, dalam hal ini modal yang dimaksud adalah harga tanah per $\mathrm{m}$ yang diperuntukan untuk lokasi pengembangan industri konsol kapal.

7) Kecukupan Infrastruktur

Infrastruktur penunjang pada penelitian ini adalah listrik, air bersih, telepon, dan jaringan jalan.

\section{METODOLOGI PENELITIAN}

\section{A. Tahap Latar Belakang Masalah}

Tahap ini adalah bagian yang berisi latar belakang masalah yang berisikan kemampuan industri penunjang dan pendukung Nasional yang masih rendah. Salah satu industri penunjang dan pendukung adalah industri konsol kapal. Industri ini sangat potensial di Indonesia dikarenakan tingkat permintaan yang tinggi dan persaingan yang masih rendah. Dengan adanya pengembangan industri konsol kapal di Indonesia, diharapkan dapat menyokong industri perkapalan Indonesia untuk mengurangi biaya pembangunan kapal. Sehingga dapat meningkatkan daya saing terhadap industri perkapalan luar negeri.

\section{B. Tahap Perumusan Masalah}

Perumusan masalah dalam penelitian ini adalah nilai estimasi permintaan konsol kapal untuk kebutuhan di Indonesia pada tahun 2016-2020, analisa teknis dan ekonomis pengembangan industri pendukung konsol kapal di Indonesia.

\section{Tahap Pengumpulan Data.}

Tahapan ini adalah pengumpulan data yang menunjang dalam penelitian ini terdiri atas: Data penjualan bridge control console dan engine control console pada tahun 2011-2015. Data ini diperoleh dari PT. Teknik Tadakara Sumberkarya yang merupakan produsen marine and industrial switchboard manufacturing.

\section{Tahap Pengolahan Data}

Pada tahap ini data yang sudah diperoleh kemudian diolah untuk digunakan tahap selanjutnya pada penyusunan tugas akhir ini, pengolahan data ini meliputi:

1) Proyeksi pembangunan kapal baru

2) Proyeksi permintaan konsol kapal

\section{E. Tahap Analisa Teknis}

Pada tahap ini yang dilakukan adalah pemilihan lokasi, proses pembuatan produk, pemeriksaan hasil produksi, peralatan dan mesin yang digunakan untuk proses produksi, perhitungan kapasitas produksi, jadwal produksi, layout dari pabrik, dan standar keselamatan kerja.

\section{F. Tahap Analisa Ekonomis}

Setelah diketahui analisa teknis dan aspek lainnya, maka langkah selanjutnya adalah analisa secara ekonomis. Pada tahap ini yang dilakukan adalah penentuan biaya pengembangan, biaya operasional, penentuan harga pokok produksi, pesaing usaha, penentuan penjualan produk, target produksi, kelayakan investasi, dan strategi pemasaran.

\section{G. Tahap Kesimpulan dan Saran}

Tahap ini adalah berupa kesimpulan dari analisa-analisa yang telah dilakukan sebelumnya, serta dikemukakan saransaran yang diperlukan untuk pengembangan lebih lanjut dari Tugas Akhir ini.

\section{PENGUMPULAN DAN PENGOLAHAN DATA}

\section{A. Pengumpulan Data}

Pengumpulan data diperoleh dari PT. Teknik Tadakara Sumberkarya berupa data penjualan dan harga jual dari bridge control console dan engine control console. PT. Teknik Tadakara Sumberkarya merupakan perusahaan marine and industrial switchboard manufacturing. Data yang diperoleh dari pihak konsumen didapat dari PT. PAL Indonesia yang berupa banyaknya pembelian produk konsol kapal pertahun.

\section{B. Pengolahan Data}

yaitu peramalan dan perencanaan produk. Untuk peramalan dilakukan pengolahan data pembangunan kapal baru dari tahun 2011 sampai dengan tahun 2015. Dari hasil peramalan yang nantinya akan menjadi acuan dari kondisi pasar untuk 5 tahun yang akan datang. Berikut adalah proyeksi pembangunan kapal baru dan proyeksi permintaan konsol kapal:

1) Proyeksi Pembangunan Kapal Baru 
Untuk mengetahui permintaan konsol kapal pada pembangunan kapal baru, maka dilakukan peramalan permintaan konsol kapal yang diperoleh dari kapal yang diproduksi. Data yang diperoleh dari website World Shipping Register (www.world-ships.com). Asumsi yang digunakan untuk menemukan data kapal yang merupakan bangunan baru dengan kelas Biro Klasifikasi Indonesia (BKI) yang diawasi dan diregister oleh BKI (dibangun oleh galangan di Indonesia) yang dibangun pada tahun 2011-2015 dengan semua bendera.

Dilakukan peramalan perhitungan nilai Main Square Error (MSE) kapal dengan menggunakan metode moving average dan exponential smoothing untuk tiap jenis kapal pada tahun 2011-2015. Dari kedua metode tersebut, kemudian dicari nilai MSE terkecil untuk tiap jenis kapal yang akan digunakan sebagai hasil dari perhitungan peramalan. Sehingga peramalan tersebut dapat dilihat pada Tabel 1, sebagai berikut:

Tabel 1.

Hasil Peramalan Pembangunan Kapal Baru Tahun 2016-2020

\begin{tabular}{lccccc}
\hline \multirow{2}{*}{ Jenis Kapal } & \multicolumn{5}{c}{ Tahun (unit) } \\
\cline { 2 - 6 } & 2016 & 2017 & 2018 & 2019 & 202 \\
& 4 & 4 & 4 & 4 & 4 \\
\hline Cargo ship & 5 & 5 & 5 & 5 & 5 \\
Container ship & 21 & 20 & 21 & 21 & 20 \\
Tanker & 34 & 33 & 35 & 34 & 34 \\
Passenger/ferry & 134 & 136 & 135 & 135 & 136 \\
Other ship & & & & & \\
(tug boat, kapal ikan, dll) & $\mathbf{1 9 8}$ & $\mathbf{1 9 8}$ & $\mathbf{2 0 0}$ & $\mathbf{1 9 9}$ & $\mathbf{1 9 9}$ \\
Jumlah kapal & & & & & \\
\hline \hline
\end{tabular}

Berdasarkan data diatas diidapatkan hasil peramalan pembangunan kapal baru tahun 2016-2020 adalah 198, 198, 200, 199, dan 199 unit.

2) Proyeksi Permintaan Konsol Kapal

Jumlah permintaan konsol kapal di Indonesia pada tahun 2016-2020 dapat dihitung setelah diketahui proyeksi jumlah kapal yang akan dibangun pada tabel 1 . Kebutuhan akan konsol berbeda untuk masing-masing jenis kapal.

Dalam penentuan jumlah konsol kapal niaga, seperti: cargo, tanker, dan container membutuhkan 5 macam konsol kapal, yaitu: BCC, ECC, CCC, WBCC, dan BWCC. Pada kapal passenger/ferry membutuhkan 4 macam konsol kapal, yaitu: BCC, ECC, WBCC, dan BWCC. Sedangkan pada kapal other ship (tug boat, kapal ikan, dll) membutuhkan 3 macam konsol kapal, yaitu: BCC, ECC, dan WBCC. Dari asumsi jumlah kebutuhan konsol kapal dan jumlah peramalan pembangunan kapal baru di Indonesia, maka dapat dihitung jumlah estimasi permintaan konsol kapal pada tahun 2016-2020 pada Tabel 2, sebagai berikut:

Tabel 2.

Proyeksi Permintaan Konsol Kapal

\begin{tabular}{|c|c|c|c|c|c|}
\hline \multirow{2}{*}{ Nama Produk } & \multicolumn{5}{|c|}{ Tahun } \\
\hline & 2016 & 2017 & 2018 & 2019 & 2020 \\
\hline Bridge Control Console & 198 & 198 & 200 & 199 & 199 \\
\hline Engine Control Console & 198 & 198 & 200 & 199 & 199 \\
\hline Cargo Control Console & 30 & 29 & 30 & 30 & 29 \\
\hline $\begin{array}{l}\text { Water Ballast Control } \\
\text { Console }\end{array}$ & 198 & 198 & 200 & 199 & 199 \\
\hline $\begin{array}{l}\text { Bridge Wing Control } \\
\text { Console }\end{array}$ & 64 & 62 & 65 & 64 & 63 \\
\hline Total & 688 & 685 & 695 & 691 & 689 \\
\hline
\end{tabular}

Berdasarkan data diatas diidapatkan proyeksi permintaan konsol kapal tahun 2016-2020 adalah 688, 685, 695, 691, dan 689 unit.

\section{PERENCANAAN INDUSTRI KONSOL KAPAL}

\section{A. Analisa Teknis}

Dalam analisa teknis dilakukan beberapa analisa pemilihan lokasi industri konsol kapal, proses pembuatan produk, pemeriksaan hasil produksi, peralatan dan mesin yang dibutuhkan, perhitungan kapasitas produksi, jadwal produksi, layout pabrik, dan standar keselamatan kerja. Berikut adalah penjelasannya:

1) Pemilihan Lokasi Industri Konsol Kapal

Dalam kriteria penentuan lokasi industri dilakukan beberapa pertimbangan, yaitu: kondisi lahan, ketersediaan tenaga kerja, ketersediaan bahan baku, pemasaran, rencana tata ruang terkait penentuan lokasi, modal, dan kecukupan infrastruktur. Lokasi yang dilakukan penilaian adalah Jl. Akses Tol Cilegon Timur, Kec. Cilegon, Kota Cilegon, Banten dan Desa Karangploso, Kec. Benjeng, Kab. Gresik, Jawa Timur. Berikut adalah bobot dari pertimbangan pemilihan lokasi:

$$
\text { Tabel } 3 .
$$

Pertimbangan Pemilihan Lokasi Industri Konsol Kapal

\begin{tabular}{|c|c|c|c|}
\hline Pertimbangan & Bobot & Sub Pertimbangan & Bobot \\
\hline Kondisi Lahan & 0.157 & $\begin{array}{l}\text { Kemampuan Lahan } \\
\text { Penggunaan Lahan }\end{array}$ & $\begin{array}{l}0.079 \\
0.079\end{array}$ \\
\hline $\begin{array}{l}\text { Ketersediaan } \\
\text { Tenaga Kerja }\end{array}$ & 0.066 & $\begin{array}{l}\text { Ketersediaan Tenaga } \\
\text { Kerja } \\
\text { Kuantitas bahan baku }\end{array}$ & $\begin{array}{l}0.066 \\
0.056\end{array}$ \\
\hline $\begin{array}{l}\text { Ketersediaan } \\
\text { Bahan Baku }\end{array}$ & 0.169 & $\begin{array}{l}\text { Kontinuitas bahan } \\
\text { baku } \\
\text { Jarak bahan baku }\end{array}$ & $\begin{array}{l}0.056 \\
0.056\end{array}$ \\
\hline Pemasaran & 0.161 & $\begin{array}{l}\text { Adanya galangan dan } \\
\text { pesaing }\end{array}$ & 0.161 \\
\hline $\begin{array}{l}\text { Rencana Tata } \\
\text { Ruang Terkait }\end{array}$ & 0.049 & $\begin{array}{l}\text { Rencana Tata ruang } \\
\text { terkait }\end{array}$ & 0.049 \\
\hline Modal & 0.255 & Harga tanah per m & 0.255 \\
\hline $\begin{array}{l}\text { Kecukupan } \\
\text { Infrastruktur }\end{array}$ & 0.143 & $\begin{array}{l}\text { Kecukupan listrik dan } \\
\text { telepon } \\
\text { Kecukupan air } \\
\text { Kecukupan jaringan } \\
\text { jalan }\end{array}$ & $\begin{array}{l}0.048 \\
0.048 \\
0.048\end{array}$ \\
\hline Total & 1 & & 1 \\
\hline
\end{tabular}

Data diatas digunakan untuk perhitungan penilaian penentuan lokasi. Berdasarkan hasil perhitungan penilaian penentuan lokasi, maka didapatkan bahwa pemilihan lokasi untuk pengembangan industri konsol kapal adalah lokasi kedua dengan nilai 0.509 yang terdapat di Desa Karangploso, Kec. Benjeng, Kab. Gresik, Jawa Timur.

\section{2) Proses Pembuatan Produk}

Pada proses pembuatan produk dibutuhkan beberapa tahap. Dimulai dari proses desain konsol kapal, fabrikasi dan Assembly (persiapan, pemotongan, bending, perakitan, pengelasan, cut out), painting (persiapan, pembersihan, pengecatan), electrical (pemasangan komponen, keamanan, ventilasi, koneksi, proteksi kabel, jalur kabel, dll), pengujian (visual check, function test, internal shop test dan official shop 
test), delivery, dan commissioning. Berikut adalah alur proses pembuatan konsol kapal:

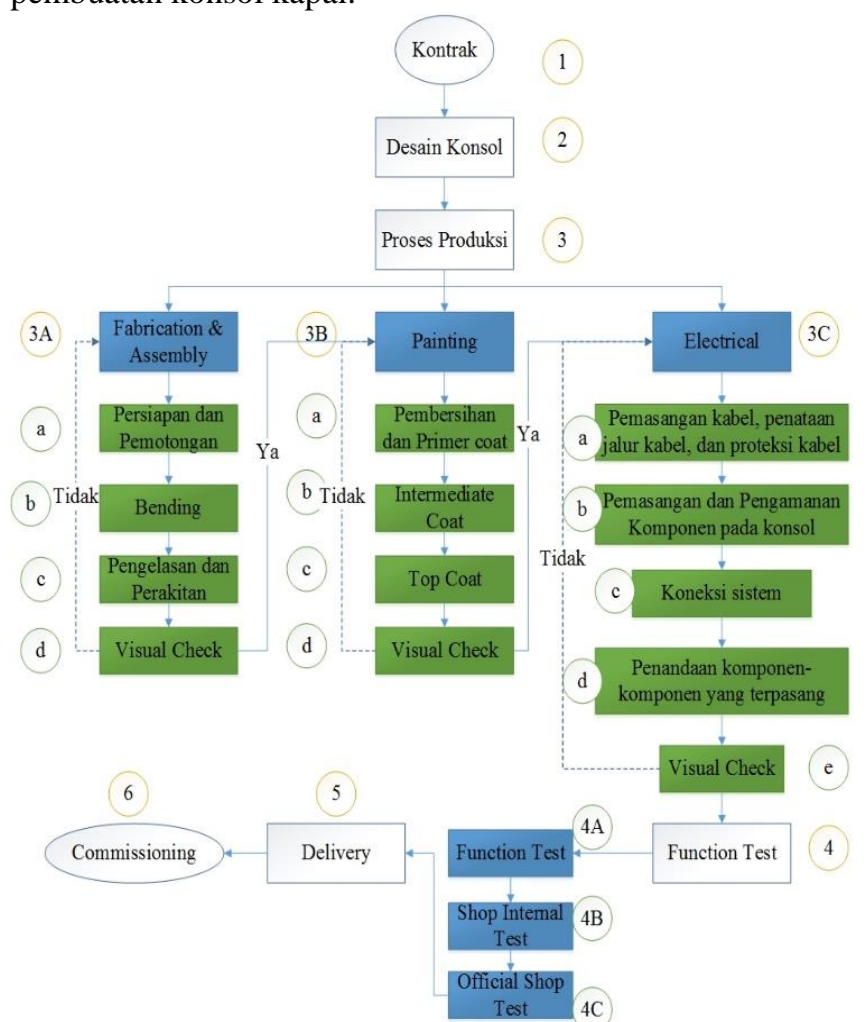

Gambar. 1. Alur Pembuatan Konsol Kapal mulai dari kontrak, desain konsol, proses produksi (fabrication \& assembly, painting, electrical), function test, delivery, dan commissioning

\section{3) Peralatan dan Mesin}

Penentuan peralatan dan mesin produksi bergantung pada proses yang terjadi didalam industri pembuatan konsol kapal di Indonesia. Selain peralatan tersebut dibagi dalam beberapa bengkel kerja/workshop sesuai dengan fungsinya. Selain peralatan dan mesin produksi, juga dibutuhkan peralatan untuk handling dan transporting.

4) Perhitungan Kapasitas Produksi

Kapasitas produksi dari industri konsol kapal sebanyak 695 buah konsol kapal yang terdiri dari 200-unit BCC, 200 unit ECC, 30 unit CCC, 200 unit WBCC, dan 65 unit BWCC.

5) Jadwal Produksi

Jadwal produksi untuk penyelesaian dari tiap produk adalah bridge control console 21 hari, engine control console 20 hari, cargo control console 20 hari, water ballast control console 16 hari, dan bridge wing control console 16 hari.

6) Layout Pabrik

Perencanaan letak pengerjaan produksi konsol dan alur produksi perlu dibuat dengan efisien. Layout tersebut harus mencakup tahapan produksi utama konsol kapal, yaitu: Assembly, painting, dan electrical. Melalui perencanaan penyusunan peralatan dan mesin, serta alur produksi dalam workshop dapat dihasilkan proses produksi yang efektif dan effisien, seperti: teraturnya aliran kerja, mengurangi perpindahan material, mendapatkan ruang kerja yang nyaman, mengurangi biaya produksi, memungkinkan pengawasan produksi dan komunikasi yang baik, dan menjaga kesehatan

fisik dan psikis para pekerja. Berikut adalah layout dari industri konsol kapal:

\section{LAYOUT LANTAI 1 WORKSHOP}

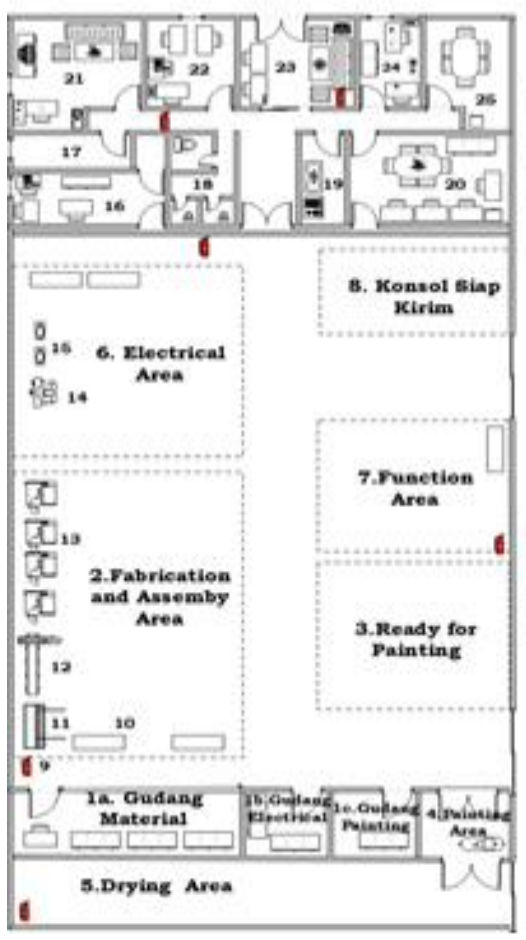

Gambar. 2. Layout Lantai 1 Workshop Industri Konsol Kapal

\section{B. Analisa Ekonomis}

Dalam analisa ekonomis dilakukan analisa mengenai penentuan biaya pengembangan, biaya operasional, penentuan harga pokok produksi, pesaing usaha, penentuan harga penjualan produk, target produksi dan pendapatan, kelayakan investasi, sensitivitas, dan strategi pemasaran produk. Berikut adalah penjelasannya:

1) Analisa Penentuan Biaya Pengembangan

Hal yang dilakukan adalah menentukan besarnya investasi pembangunan industri konsol kapal. Berikut adalah hasil rekapitulasi dari total investasi industri konsol kapal:

Tabel 4.

Rekapitulasi Total Investasi Industri Konsol Kapal

\begin{tabular}{lr}
\hline \multicolumn{1}{c}{ Uraian } & \multicolumn{1}{c}{ Total (Rp.) } \\
\hline Bangunan dan tanah & $10,789,550,000.00$ \\
Peralatan Software desain & $331,903,719.20$ \\
Peralatan untuk handling dan transporting & $1,194,760,000.00$ \\
Peralatan manual & $12,650,000.00$ \\
Peralatan dan mesin proses fabrikasi dan & $700,140,400.00$ \\
assembly & \\
Peralatan dan mesin proses painting & $885,992,000.00$ \\
Perlengkapan kantor & $252,350,000.00$ \\
Perlengkapan keselamatan & $17,880,000.00$ \\
Total & $\mathbf{1 4 , 1 8 5 , 2 2 6 , 1 1 9 . 2 0}$ \\
\hline \hline
\end{tabular}

Berdasarkan data diatas didapatkan total investasi untuk pengembangan industri konsol kapal adalah $\mathrm{Rp}$ 14,185,226,119.20.

2) Analisa Biaya Operasional 
Biaya-biaya operasional yang akan dikeluarkan saat industri konsol kapal berjalan dalam setahun seperti gaji karyawan (organik), biaya tagihan listrik, dan air, serta biaya pemeliharaan peralatan dan mesin.

3) Analisa Penentuan Harga Pokok Produksi

Penentuan harga pokok produksi adalah cara untuk memperhitungkan unsur-unsur biaya ke dalam harga pokok produksi.

4) Analisa Pesaing Usaha

Untuk menentukan strategi perusahaan dan harga penjualan dari produk konsol kapal diperlukan analisa pesaing usaha.

5) Analisa Penentuan Harga Penjualan Produk Konsol Kapal

Untuk menentukan besarnya penentuan harga penjualan produk konsol kapal dilakukan perhitungan dengan menambahkan mark up $20 \%$ dari Harga Pokok Produksi.

6) Analisa Target Produksi

Analisa target produksi diperlukan untuk mendapatkan keuntungan dengan pertimbangan yang matang sesuai dengan kapasitas produksi dan ketersediaan tenaga kerja.

7) Analisa Kelayakan Investasi

Analisa kelayakan investasi yang digunakan adalah Pay Back Period, Net Present Value, dan Internal Rate of Return. Berikut adalah hasil rekapitulasi dari analisa kelayakan investasi industri konsol kapal:

Tabel 5.

Analisa Kelayakan Investasi Industri Konsol Kapal

\begin{tabular}{ll}
\hline \multicolumn{1}{c}{ Parameter } & \multicolumn{1}{c}{ Value } \\
\hline Break Event Point & \multicolumn{1}{c}{ Rp 1.506.810.280,35 } \\
Pay Back Period & 6 tahun 8 bulan \\
Net Present Value & Rp 4.407.374.076,52 \\
Internal Rate of Return & $11.38 \%$ \\
\hline \hline
\end{tabular}

Berdasarkan data diatas didapatkan bahwa Pay Back Period terjadi pada 6 tahun 8 bulan dengan keuntungan sebesar Rp 1.506.810.280,35. Nilai NPV sebesar Rp 4.407.374.076,52. Nilai IRR sebesar $11.38 \%$ lebih besar dari bunga bank yang telah ditetapkan yakni $10.25 \%$.

8) Analisa Sensitivitas

Analisa sensitivitas dilakukan untuk mengetahui akibat dari perubahan parameter-parameter produksi terhadap kinerja sistem produksi dalam menghasilkan keuntungan.

9) Strategi Pemasaran Konsol Kapal

Strategi pemasaran atau cara penjualan produk merupakan faktor terpenting dalam proses berbisnis.

\section{KESIMPULAN}

Dari hasil diatas maka dapat disimpulkan :

1) Dari hasil estimasi peramalan yang dilakukan untuk tahun 2016 sampai dengan 2020, pada bridge control console adalah 198, 198, 200, 199, 199 unit. Pada engine control console adalah 198, 198, 200, 199, 199 unit. Pada cargo control console adalah 30, 29, 30, 30, 29 unit. Pada water ballast control console adalah 198, 198, 200, 199, 199 unit. Pada bridge wing control console adalah 64, 62, 65, 64, 63 unit.

2) Analisa teknis yang dihasilkan untuk pengembangan industri konsol kapal adalah sebagai berikut:

a. Konsol kapal merupakan panel listrik dari sistem yang terintegrasi yang berbentuk kotak ataupun disesuaikan dengan desain dan ruang yang tersedia di dalam kapal. Proses pembuatannya dimulai dari tahap desain, fabrikasi dan assembly, painting, electrical, function test, delivery, dan commissioning. Material yang digunakan merupakan pelat baja tipis dengan ketebalan 2-5 mm. Sehingga dibutuhkan teknologi khusus dalam proses perakitan dengan menggunakan mesin las spot welding yang proses penyambungannya menggunakan jenis sambungan lap joint. Kemudian dilakukan pemasangan komponen, yang diintegrasikan dalam sebuah sistem di kapal.

b. Pemilihan lokasi untuk pengembangan industri konsol kapal terletak di Desa Karangploso, Kec. Benjeng, Kab. Gresik, Jawa Timur. Layout pabrik dengan luas bangunan $2728 \mathrm{~m}^{2}$ dan luas tanah $3886 \mathrm{~m}^{2}$. Kapasitas produksi industri konsol kapal per tahun adalah 695 unit.

3) Analisa teknis yang dihasilkan untuk pengembangan industri konsol kapal di Indonesia adalah lokasi dari indusri konsol terletak di Desa Karangploso, Kec. Benjeng, Kab. Gresik, Jawa Timur, produk yang dihasilkan berupa bridge control console, engine control console, cargo control console, water ballast control console, bridge wing control console. Layout pabrik dengan luas bangunan $2728 \mathrm{~m}^{2}$ dan luas tanah $3886 \mathrm{~m}^{2}$.

4) Biaya investasi yang diperlukan dalam pengembangan industri konsol kapal kira-kira sebesar Rp 14,186,000,000.00. Break Event Point terjadi pada 6 tahun 8 bulan dengan keuntungan kira-kira sebesar Rp 1.507.000.000,00. Nilai Net Present Value kira-kira sebesar Rp 4,408,000,000.00. Nilai Internal Rate of Return sebesar $11.38 \%$ lebih besar dari bunga bank yang telah ditetapkan yakni $10.25 \%$. Sehingga investasi ini layak dilakukan di Indonesia dikarenakan potensi pasar yang luas dan jumlah kompetitor industri konsol kapal yang masih sedikit.

\section{UCAPAN TERIMA KASIH}

Penulis mengucapkan terima kasih kepada ayah dan ibu tercinta yang telah membesarkan penulis atas do'a, kasih dukungan yang tidak pernah berhenti.

Penulis juga mengucapkan terima kasih kepada Bapak Ir. Triwilaswandio Wuruk Pribadi, M.Sc selaku dosen pembimbing penelitian ini.

\section{DAFTAR PUSTAKA}

[1] Anonim, "Potensi Industri Perkapalan Nasional Jakarta," Kompas, Jakarta, 2015.

[2] Anonim, "Paket Kebijakan Jokowi Tahap II," Tempo, Jakarta, 2015.

[3] Soetrisno, Kriteria Kelayakan Investasi, Jakarta: Media Pressindo, 1992.

[4] S. Handaru, Manajemen Portofolio dan Investasi, Yogyakarta: Andi, 1999. 
[5] Kertonegoro, Studi Kelayakan Bisnis dan Investasi, Yogyakarta: Jalasutra, 1999.

[6] Baroto, Dasar-dasar Peramalan, Jakarta: Gramedia, 2002.

[7] M. Djojodipuro, "Teori Lokasi," Lembaga Penerbit Fakultas Ekonomi Universitas Indonesia, Jakarta, 1992.

[8] Dahuri, "Rencana Tata Ruang," Perencanaan Tata Ruang Wilayah dan Tata Kota, 2001. 